\title{
PREDICTIVE ANALYSIS OF RESEARCH OF THE INSTITUTIONAL ASPECTS OF MARKET ENVIRONMENT DISTORTIONS
}

\author{
Nataliia Honcharenko-Zakrevska ${ }^{1}$, Mykhailo Goncharenko² ${ }^{2}$ Liudmyla Osipova ${ }^{3}$
}

\begin{abstract}
Further changes and improvement of the conditions necessary for the development of economy, market and institutional environment should be based on gradual institutional transformations of the most important spheres of social relations, taking into account all the peculiarities of functioning of enterprises of different types of economic activity and forms of ownership. The regulation of the market environment should be based, first of all, on an institutional approach by creating an adequate support mechanism and stimulating its development. The purpose of the article is to formulate the methodological bases for the study of institutional aspects of market environment disortion on the basis of predictive analysis and institutional engineering. The authors summarize that the institutional environment has certain rules of behavior for the subjects of the socio-economic system, which reduce uncertainty in the functioning of this system, and also contribute to the growth of welfare of members of society. It has been determined that, both formal and informal, they must promote the effective functioning of economic processes and represent social value and productive force in socio-economic development in themselves, forming such a resource of society as social capital, which supplements and regulates the use of physical and human capital. The availability of social capital reduces the amount of transaction costs and, accordingly, the number of services for monitoring and controlling the behavior of participants in the economic process. It is proposed to conduct research based on predictive models of forecasting manner, that is used to predict the income and expenses of the subject and its future status. The overall macro-factor analysis of market distortions has made it possible to determine that the most comprehensive analysis of the elements of the institutional environment is carried out by the World Bank, with the help of several groups of indicators: the first group includes political liberties and political stability, the second one isthe efficiency of governance and the quality of regulatory activity, and the third one is the rule-of-law assessment of the quality of compliance of the human rights, property rights. It is also possible to determine the dynamics of the efficiency of government in the countries of Central and Eastern Europe. Predictive analysis of the market environment allowed us to consider institutional changes, both through the prism of quantitative analysis of economic agents and qualitative factors of influence (the perfection of rules, time interval for their implementation, etc.). Also, it allowed to analyze the disparities in the market environment from the point of view of trajectories formed by gradual changes and trajectories that have certain "breaks", jumps or "institutional shocks". The authors present the characteristics of the results of a predictive analysis of institutional development. It is generalized that the final assessment of institutional changes and their effectiveness can only be determined after their implementation. Pre-forecasting gives a plausible estimate of the effectiveness and a predictable estimate of chreodity of the development option. It also proposes the introduction of institutional engineering as an activity aimed at developing models of economic institutions that are consciously and purposefully introduced into the market environment and mass economic behavior. The main problem lies in the development of such rules and principles of activity, the adherence of which would contribute to the effective solution of those problems for which they were created.
\end{abstract}

Key words: countries of Central and Eastern Europe, institutionalism, institutional distortions, market distortions, predictive models, macro-factor analysis, governance effectiveness, institutional trajectories, institutional engineering.

JEL Classification: E11, E60, H77, O11, Z19

\footnotetext{
Corresponding author:

${ }^{1}$ National Aviation University, Ukraine.

E-mail: goncharenko-zakrevska@ukr.net

${ }^{2}$ Interregional Academy of Personnel Management, Ukraine.

E-mail: goncharenkomf@ukr.net

ORCID: https://orcid.org/0000-0002-6331-6518

${ }^{3}$ University of Modern Knowledge, Ukraine.

E-mail: OsipovaLW@ukr.net
} 


\section{Introduction}

Further changes and improvements to the conditions necessary for business development should be based on a gradual institutional transformation of the most important spheres of social relations, taking into account all the peculiarities of the functioning of structures of different types of economic activity. The regulation of the market environment should be based, first of all, on an institutional approach by creating an adequate support mechanism and stimulating its development.

The wish of the countries of Central and Eastern Europe for freedom, democracy, rapid integration into the civilized world and rejection of the totalitarian past were accompanied by a series of economic shocks related to the reorientation of the economy to new trading partners, rapid growth in energy prices, lack of funds to support unprofitable production and a corresponding reduction in gross domestic product and incredibly high inflation.

Almost thirty years of economic development in the post-socialist countries of Central and Eastern Europe have led to some conclusions about the successful and unsuccessful economic strategies and conditions for the sustainable growth of living standards in these countries (Djankov, Glaeser, La Porta, 2013).

The experience of institutional change in the postsocialist countries of Central and Eastern Europe, which has undergone a rather radical way, which can be seen as a kind of socio-political experiment at the global level and a good opportunity to analyze the formation of an effective institutional framework in the transition from one type of political system of economy to another, is important.

The formation of the institutional system in countries in transition comes in two parallel ways. On the one hand, the authorities are pursuing reforms that underpin the development and implementation of formal rules. On the other hand, traditions and customs (routines) serve as the institutional basis for the preservation of traditional relations based on the customary system of values and motivation of the activity of individuals. During the period of sharp breaking of the existing formal rules and norms, as well as the creation of new norms, "scissors of inconsistency" are formed between the existing traditions and the new formal institutions. In this connection, there is a problem of overcoming the existing contradiction, which can only be solved by creating an effective institutional system of a transformational society.

The changes that have taken place in recent years in Ukraine provide a wealth of empirical material for discussion in economic science on the relationship between expected and unanticipated decision-making by economic entities. Institutionalism is one of the most methodologically productive areas of economic theory in the study of the content, ways and mechanism of systemic transformation in market economies (Kovalenko, 2013). It should be noted that this is due to its general orientation towards a comprehensive study of the fundamentals of the functioning and development of economic systems in a broad social context. The fundamental prerequisite for institutional analysis of economic systems is that the economy is not limited by the market. It determines the entry of institutionalism into the field of active interdisciplinary interaction with other social sciences and involvement in the study of a wider range of variables that are not purely economic in nature, but determine the implementation of economic processes and economic development, such as: historical, social, psychological, legal, political, philosophical and ethical, ethno-cultural, etc. Due to its methodological specificity, institutionalism can be used to solve various problems, both specific and general (Brennan, Biukenen, 2005).

\section{Methodology of research}

The countries of Central and Eastern Europe represent a specific example of institutional distortions generated by an established system with an outdated ideology. Institutional change is a complex, speedy process of changing old rules of behavior, which are limiting economic development, to new ones, which provide new opportunities for increasing well-being. However, it should be noted that with the sharp transformations of the institutional structure, there are increasing opportunities to obtain certain privileges for individual social groups based on the growing asymmetry of information and the imperfection of new institutes.

In general, in the recent period, the scientific works of Nort D. (2008), Lance D., Douglass (1970), Kouz R. (1993), David P. (1985), Sukharev O.S. (2011), Hodgson J. (2006), Kleiner G.B. (2004), Veblen T. (1980) and others have updated the study of the category of institutional environment within neoclassical economic theory as a major trend in modern economic science.

According to L. Davis and D. Nort, the institutional environment is "a set of fundamental political, social and legal principal rules that guide economic and political activity (the rules that govern elections, property rights, and contract rights are examplesof such principal rules" (David, 1985; Nort, 2008). Therefore, a set of formal and informal rules is drawn up in society that limits and determines the directions of behavior of participants in a particular institutional system. In our opinion, we will understand the category of "institute" as certain rules of behavior of the subjects of the socio-economic system, which reduce uncertainty in the functioning of this system, as well as contribute to the growth of welfare of members of society. Formal institutes that regulate the behavior of the subjects of the system are the family, the firm, the market of various factors of production, the 
government, the banking system and others. We think of a particular company, bank or ministry as an institution. Certain variations in the interpretation of the institute and institution in the Ukrainian economic literature often occur. Informal institutes can be considered a set of certain values, motives, traditions and customs, as well as trust in certain formal institutes in society (Hodgson, 2006).

It has been determined that, both formal and informal, they must promote the effective functioning of economic processes and represent social value and productive force in socio-economic development in themselves, forming such a resource of society as social capital, which supplements and regulates the use of physical and human capital. The availability of social capital reduces the amount of transaction costs and, accordingly, the number of services for monitoring and controlling the behavior of participants in the economic process.

According to X. Sala-i-Martin, institutes influence the efficiency of the economy in the same way as production technologies: an economy with bad institutes is more inefficient in the sense that more resources are needed for the same volume of production (Sala-i-Martin, 2002). At the same time, bad institutes are reducing incentives to invest in physical and human capital, in new technologies. The process of introducing good or proper institutes is somewhat more complicated and different from the process of introducing new technologies.

The theory distinguishes between two types of institutional change: forced and imposed (Gukasyan, 2013). Forced institutional changes are described as a modification or replacement of an existing institutional mechanism, or the emergence of a new institutional mechanism, whether voluntarily initiated or organized, used by an individual or group of individuals to gain new opportunities for greater profitability. On the contrary, imposed institutional changes are introduced and enforced by government or law-based regulations. Forced or spontaneously initiated institutional changes should be driven by profitable revenue growth opportunities that cannot be achieved under the original institutional framework. Forced institutional changes can occur solely for the purpose of redistributing existing incomes among different groups of voters (Kleiner, 2004).

In the diagnostics of defining the distortional proportions and their impact on the market environment, models are used that allow to structure and identify the relationships between the main and indirect indicators. There are three main types of diagnostic models: 1) descriptive; 2) predictive; 3 ) normative.

Descriptive models are the main ones, they include the following: construction of a system of balance sheets, analysis of reports in vertical and horizontal analytical sections, trend analysis of performance indicators, analysis of relative indicators and ratios, comparative or spatial analysis, factor analysis, system of analytical coefficients.

Predictive models are the models of forecasting manner. They are used to forecast the income and expenses of the analysis subject and its future status (Bilenko, 2013). The most common of these are:

1) calculations of the point of critical loss (break-even analysis);

2) preparation of forecasting financial reports;

3) models of dynamic analysis;

4) models of situation analysis.

Normative models are models that make it possible to compare actual performance with the normative ones. These models are generally used in internal analysis. Their essence is to set norms for each structure characteristic for the respective technological processes and to find out the reasons for deviations of actual data from these norms.

Development of predictive models is necessary to create a general financial strategy of a structural object and to provide its resources, to evaluate its capabilities in the future. It should be based on a study of real financial opportunities, internal and external factors, and cover issues such as optimization of funds and capital, profit sharing, investment and pricing policies. The main attention is paid to the identification and mobilization of internal reserves to increase cash income, the formation of a rational policy for the distribution of profits, the efficient use of capital at all stages of the entity's life.

The value of forecasting analysis of predictive models is that it allows you to assess the financial situation in advance from the point of view of its compliance with the development strategy, taking into account changes in the internal and external conditions of the market environment and its functioning. Usually there are four methods of forecasting the financial state of an object: extrapolation; method of periods of turnover; budgeting method; method of preliminary (forecasting) results.

\section{Results and discussion}

\subsection{General macro-factor analysis of market environment distortions}

An effective institutional mechanism can be selected from the many possible ones, given both the production and transaction costs of its implementation. Since the transaction costs of implementing certain social agreements depend on other mechanisms (e.g., laws, customs and ideologies), the most effective institutional mechanism is a function of these agreements in the institutional structure. Justin Yifu Lin emphasizes that "forced institutional changes occur when there are certain opportunities to achieve additional benefits and arise in violation of institutional equilibrium, that is, there must be some reason that the existing institutional mechanism is no longer the most effective in the system of institutional choice" (Lin, 1989). 
Institutional changes in the countries of Central and Eastern Europe combined such economic phenomena that are associated with long-term economic stagnation, lack of economic growth and total deficits in the consumer market, since integration into global financial and economic institutions required changes in legislation, promulgation and liberalization of all the processes of socio-economic life.

This gives grounds for a thorough analysis of the whole spectrum of changes in the institutional environment of countries, and these changes are quite revolutionary and distinguished by different regions (Sukharev, 2011; Bolotina, Shubnaya, 2016).

A number of international organizations conduct systematic studies of the quality of the country's institutes on a long-term basis, enabling the results to be included in a formalized economic analysis. The most comprehensive analysis of the elements of the institutional environment is carried out by the World Bank, which forms a worldwide base of governance indicators, which understands the traditions and institutes through which power is exercised in the country, in particular the processes of selecting, controlling and replacing government; the ability of the government to effectively formulate and implement sound policies, as well as the respect of the population and the state for the institutions that manage economic and social interactions between them (Kaufmann D. Kraay and M. Mastruzzi, 2010).

The first group of indicators includes political liberties and political stability, the second one is the efficiency of governance and the quality of regulatory activity, the third one is the rule-of-law assessment of the quality of compliance of the human rights, property rights, as well as the quality of the judiciary, law enforcement agencies and the control of corruption, encompassing state power is used for private gain.

Analysis of the second group of quality indicators of institutes that are important for successful economic development: the efficiency of governance and the quality of regulatory activity shows a significant differentiation of these indicators among the postsocialist countries of Central and Eastern Europe (measurements are based on percentage ranking, determining the country's place on the level of quality of the institutional environment from 1 to $100 \%$, that is, the best in the institutional environment of the state will be in the higher percentile groups). The countries of Central Europe and the Baltic countries, which were between $70-80 \%$ in 2011 , demonstrate steady dynamics of improving governance efficiency since 1996; reverse dynamics, although in the upper group, is demonstrated by Hungary and Poland (Bilenko, 2013)

Among the European CIS countries, the lowest indicators for 2011 are for Belarus - 13.7\%, Ukraine $-21.8 \%$, and the Russian Federation $-42.2 \%$. In 2017, trends showed an increase in the indicator in all countries, with the highest figures in the Czech Republic - 81.9\% and Slovenia - 80.5\%. Among the post-Soviet countries, the highest rate is in the Russian Federation - 39.8\%. The peculiarity of prominent countries is that the dynamics in these indicators are almost absent, that is, institutional reforms are not implemented, and therefore there is degradation and dysfunction of socio-economic institutes. The level of economic development directly correlates with the quality of the institutional environment. In addition, the vulnerability to external financial and economic shocks increases with stable long-term strains of the institutional environment.

Let us try to analyze the nature of institutional distortions in post-Soviet countries (in particular, in Ukraine) in the context of economic development.

Let us briefly dwell on the analysis of the main phases of the reform of the command and administrative economic system of the countries of Central and Eastern Europe. The first phase (1990-1994) was the rapid liberalization

Table 1

Dynamics of Public Governance Efficiency in the countries of Central and Eastern Europe

\begin{tabular}{|c|c|c|c|c|}
\hline \multirow{2}{*}{ Countries } & \multicolumn{4}{|c|}{ Public Government Efficiency, \% } \\
\hline & 2000 & 2005 & 2011 & 2017 \\
\hline The EU member countries - average figures & 71.8 & 75.2 & 75.2 & 76.0 \\
\hline The Czech Republic & 75.1 & 81.0 & 81.5 & 81.9 \\
\hline Hungary & 81.0 & 75.6 & 73.0 & 73.8 \\
\hline Latvia & 62.9 & 70.7 & 72.5 & 73.2 \\
\hline Lithuania & 60.5 & 74.6 & 72.0 & 72.8 \\
\hline Poland & 73.2 & 68.3 & 71.6 & 73.1 \\
\hline The Slovak Republic & 71.7 & 78.5 & 76.3 & 77.2 \\
\hline Slovenia & 78.5 & 77.6 & 79.6 & 80.5 \\
\hline Post-Soviet countries - average figures & 27.17 & 27.5 & 27.8 & 30.2 \\
\hline Belarus & 28.3 & 12.7 & 13.7 & 14.5 \\
\hline Moldova & 30.7 & 26.3 & 33.6 & 33.4 \\
\hline The Russian Federation & 26.3 & 38,0 & 42.2 & 39.8 \\
\hline Ukraine & 23.4 & 33.2 & 21.8 & 33.2 \\
\hline
\end{tabular}

Source: The Worldwide Governance indicators. Available from: http://info.worldbank.org/wgi 
of commodity and foreign exchange markets, the opening up of the economy to foreign goods and investors. In this phase, we can already observe two trajectories of economic development in the countries of Eastern Europe (Poland, Hungary, the Czech Republic, the Slovak Republic, Slovenia) and the post-Soviet European independent countries (Ukraine, the russian Federation, Belarus, Moldova, Georgia). In particular, for the first group of countries, economic liberalization was carried out for almost all groups of goods and markets, and was accompanied by the creation of new efficient markettype institutions. For the second group (the post-Soviet countries), liberal reforms have been compounded by an even greater imbalance in the economy and tight monetary stabilization to overcome hyperinflation without creating both institutes and the real market-type institutions and a decline in gross domestic product (Borovkov, 2013).

The process of realization of social opportunities of the country is rather slowed down because the formation of the middle class is stopped, bourgeoisie wins, the former political elite begins to reap the economic benefits: profits, dividends on shares, redistribution of budget funds in their favor. The policy of eliminating the middle class causes a reduction in resistance to the dictatorship, as well as destroys the social potential of technological innovation. The results are the de-industrialization, de-professionalization of the economy (Yaremenko, 2007). Although the initial potential was quite high, the reason, in our opinion, is that human capital (education level) is quite significant, but it is not supplemented by social capital. Consequently, the external effects of high levels of education in educational institutions and the rising incomes disappeared. Higher education focused on academic humanities education. The lack of filters, sufficiently clear and effectively controlled criteria leads to a lack of meaningful action in a public context, causes weakness or, in general, lack of professionalism, consistency, experience, constant change.

The classical scheme of development of resourcebased branches caused the monopolization of industry, the economy did not begin to work for a person, and economic growth was not caused by a high level of capital, a high level of savings.

The imbalance in the labor and capital markets is caused by an institutional component, in particular the directorate corps, which, having gained freedom of action, aggressively and uncontrollably aggravates the deformation of these markets in order to obtain extra profits and create oligarchic structures in the industrial, banking and political environment (Martynyuk, 2015).

\subsection{Predictive analysis of the market environment}

In predictive analysis, institutional changes should be considered both through the prism of quantitative analysis of economic agents and qualitative factors of influence (the perfection of rules, the time interval for their implementation, etc.). After all, in some cases changes to institutes, such as tax laws that reduce the tax burden of the country, are almost instant increase in the number of taxpayers; for others, such as the business tradition of conscientious performance of contracts, attracting new business supporters may take a long time, etc. Different institutional changes undergo different trajectories of development. To describe these trajectories in quantitative terms, let us consider the dynamics of the spread of institutional change in a market environment.

Qualitative changes in the institutional trajectory of development mean the sequence of changes that a particular (basic) institute undergoes.

To determine the trajectories of change of institutes, there are two essentially different types of them in a predicative analysis:

1) trajectories formed by gradual changes;

2) trajectories, such as certain "breaks" containing, jumps or "institutional shocks", when one institute ceases to operate and its function in the economy is started by another institute (or a whole group).

According to the classification of institutional changes, the trajectory of the second type can be characterized as those including discrete changes.

The institutional changes in the trajectory that arise in the process of evolution are not unreasonable in nature, but obey certain patterns, called the "trajectories of stochastic extrapolation development."

The frequency of institutional changes and policy decisions that provoke such changes in the modern economy in the most developed countries, far outstrips agents' ability to act and accomplish tasks, to bring solutions to the outcome (Gukasyan, 2013).

For probabilistic and measurable spaces, a stochastic process is a set of random variables that can be written as:

$$
\{X(t): t \in T\}
$$

In many issues of institutional change analysis, the point $\mathrm{t}$ is the value of time, $\mathrm{X}$ is a random variable that represents the value observed over time $t$. But such a stochastic process can also be written to reflect the values, two variables, and functions.

Therefore, when designing a new institute, it is necessary to take into account the reactions of agents and other institutes that are intended to interact with it. The complexity of the research of this process is that even with the introduction of one institute, its interaction with many other institutes is difficult to predict.

By predictive analysis of institutional changes, we understand the set of actions for the formation of institutes, their introduction into the market environment, change, correction, borrowing of institutes (planning changes in legislation, new legal rules, organizational forms and their changes). Institutional design in the general sense is interpreted as a method of 
creating institutes, often in terminological terms, these concepts are almost identical. This is the fundamental difference between these ideas and the two approaches.

In the first case, it is precisely the dysfunction that causes the blocking effect, in the second, on the contrary, the blocking effect produces dysfunction.

A little has been done in predictive analysis of the managed replacement of one institute by another and the choice of the preferred mode of institutional dynamics ("path dependence/independence" or path determinancy) in economic science and, more specifically, in institutional theory (Kleiner, 2004).

Most macroeconomic models go beyond the minimal impact of institutes on economic dynamics and decision-making. Adaptation of structures to new rules, or changes in the content of old rules, which for this reason are undergoing updating or correction, determines the quality level of passage or obstruction of a given rule or set of rules. And, as a rule, this is not taken into account by modern macroeconomic science.

In other words, institutional forecasting is an algorithm that justifies the sequence of management of institutes, their functioning, the creation of a mode of adaptation to new rules, substitution, etc. It should be an integral part and mainstay of government, but it can be carried out at the level of the government, the legislature, at the level of regional power, and even at the level of the firm and individual household, which establish the rules of their functioning and making everyday economic decisions. At each level, institutional engineering has its own specificity and significance. Laws approved by parliament have a higher priority and power than regional legislation. However, by power of execution, a regional legal act may have a clear advantage.

Another reverse scenario may also be present. In conclusion, it is worth mentioning that institutes have different powers, purposes, and differently regulate the same processes in the economy, so the cumulative effect of the impact is difficult to assess. In addition, when talking about different modes of development of institutes, they use the terms of path dependence, path independence or path determinancy. It is understood that the new institutes reveal three of these modes of communication with the old institutes. In fact, it is possible to establish the existence of a particular regime only by a separate institute, but if we consider the interaction of all institutes with each other, and in society there is a single institutional and market space, then it is rather implausible to speak of path independence even in the face of revolutionary changes.

The emergence of new technology and techniques is, on the one hand, a minor revolutionary change, but if the scale of such change is significant, then there is a change in the mode of production, a significant increase in productivity and expansion of technological capabilities in the country, and this affects the market environment in general. On the other hand, new techniques and technologies give rise to new rules, algorithms for actions, including those related to the maintenance of this technique, but these rules incorporate certain algorithms for servicing old technical analogues, so whatever the technical leap in development forward, generations of techniques imitate one another more or less consistently. Therefore, path dependence is always there: this is how knowledge is built up, and how new knowledge arises, usually on the basis of previous accumulated knowledge. Even a paradigm shift is made on the basis of criticism, therefore, also based on a detailed study and understanding of the former paradigm of knowledge (Hodgson, 2006; Bolotina, Shubnaya, 2016).

The choice of an institutional development trajectory, as a rule, does not occur according to a strict criterion or some cost ratio. That is to say, chance plays a major role here: no authority endowed with adequate institutional planning methods and taking into account the sufficient number of predicative criteria required for forecasting. In this regard, it is difficult to talk about what the cost ratio will be when implementing the chosen scenario.

Undoubtedly, agents who make decisions on the formation of a vector of institutional development are dependent on cost ratio parameters. From the perspective of predictive analysis of institutional engineering, it is advisable to evaluate the trajectory of development, the state of institutes in each case, using preferably the same evaluation criteria for different countries, firms, organizations, institutional systems.

When planning institutes, it is important not only to ensure the regime, whether of path independence or path determinancy, but also to take into account the time of introduction of the institute, the push of this institute to the highest efficiency and the need for future correction or replacement of the institute after a certain time. The situation in this area of activity and economic and institutional forecasting is developing more scholastically than consistently (Tambovtsev, 2005; Yaremenko, 2007).

Determining the chreod trajectory of development is a difficult task, since it is sometimes difficult to answer which mode of development of path dependence, path independence or path determinancy will be a chreod one.

If we consider these issues based on the principles of institutional forecasting, combined with a predictive analysis of the market environment, prospective cost estimates and quality parameters, peer review will have a high correlation coefficient. Let us generate a forecast for the three baseline scenarios based on the following criteria (see Table 2).

As it can be seen from the presented characteristics, the most costly, poorly predicted from the point of quality of change is the mode of institutional development of path independence.

It is this mode that can be considered as falling under the chreod effect, although with an imbalanced 
system a vector that takes it to a whole new level of development can be found (Sukharev, 2011; Holubka, 2015).

In any case, the presence of such effects as the "lock in", "QWERTY", is associated with dysfunction of institutions and with the inability to predict the effectiveness of future features of the market environment, institutional and technological development.

It is generalized that the final assessment of institutional changes and their effectiveness can only be determined after their implementation. Pre-forecasting gives a plausible estimate of the effectiveness and a predictable estimate of chreodity of the development option (David, 1985).

As we can see, time becomes a very significant limitation in assessing the efficiency and rationality of determining the vector of development, with the introduction of new institutes, in determining the reactions of agents and the formation of models of their adaptation. Time determines the quality and efficiency of transactions, the effectiveness of management and other decisions made, including decisions aimed at choosing the development trajectory of institutionalism. All these questions form, determine the list of tasks and methods that need to be addressed within institutional forecasting and engineering.

If the scenario of institutional change from the previous development trajectory is selected, it considers a situation in which, at any given moment in the economy, not any (arbitrary) institutional changes, but only deterministic ones, can occur, which can be implemented in the prevailing conditions and which, in turn, arose as a consequence of the previous similar situations.

Only the institutional change will enter into mass practice, the benefits of which will be higher than the costs of moving to a new rule. Obviously, such a transition can also be ensured by artificially reducing the effectiveness of the use of the old rule, for example by dramatically increasing the amount of sanctions imposed by the state on individuals. This loses the value of previously created human capital, specific to the old rule, but the total expected benefit of using the new rule, taking into account discounting, fully compensates for such losses.

This concept denies the possibility of convergence of economic systems, which were initially based on nonoverlapping institutional structures.

Institutional engineering refers to activities aimed at developing models of economic institutes that are consciously and purposefully introduced into the market environment and mass economic behavior. The main problem lies in the development of such rules and principles of activity, the adherence of which would contribute to the effective solution of those problems for which they were created.

The basic elements of the institutional system are transactions, contracts, and deals. Throughout the transition period, the Ukrainian economy has shown a very low degree of contract performance. The payments for the delivered products were not made on time, the salary was delayed, dividends were not paid, credit agreements were not executed. "Out-of-contract" behavior has become almost the norm of business relations.

A similar situation is inevitable for a transitional society in which the former institutional framework has already been broken and a new one has not been built yet. This means that the institutes that did not exist under the socialist system were not created, such as:

- legally qualified private property;

- numerous legal institutes (codes, laws);

- institutes that determine responsibility for the property of others (optimal notms of accounting, banking regulation, securities market regulation);

Table 2

The authors present the characteristics of the results of a predictive analysis of institutional development

\begin{tabular}{|l|l|l|l|}
\hline \multicolumn{1}{|c|}{ Criteria } & \multicolumn{1}{|c|}{ Path dependence } & \multicolumn{1}{c|}{ Path independence } & \multicolumn{1}{c|}{ Path determinancy } \\
\hline The goal of the vector & $\begin{array}{l}\text { Introduction of new institutes } \\
\text { while preserving old institutional } \\
\text { forms }\end{array}$ & $\begin{array}{l}\text { Introduction of new institutes } \\
\text { while preserving old institutional } \\
\text { forms }\end{array}$ & $\begin{array}{l}\text { Introduction of new institutes } \\
\text { while preserving old institutional } \\
\text { forms }\end{array}$ \\
\hline Effort area & $\begin{array}{l}\text { Development of old institutes on } \\
\text { the basis of correction }\end{array}$ & Formation of new institutes & Formation of new institutes \\
\hline Functional filling & $\begin{array}{l}\text { Defined by the old functions of } \\
\text { the institutes }\end{array}$ & $\begin{array}{l}\text { Determined by the new functions } \\
\text { of the institutes }\end{array}$ & $\begin{array}{l}\text { Interconnection of old and new } \\
\text { institutions }\end{array}$ \\
\hline Sensitivity to the term of change & $\begin{array}{l}\text { Depends on the scale of } \\
\text { dysfunction of the old institutes }\end{array}$ & $\begin{array}{l}\text { It is determined by the degree of } \\
\text { rejection of new adaptive norms } \\
\text { and the adequacy of the reactions } \\
\text { of agents }\end{array}$ & $\begin{array}{l}\text { It depends on the overall effect of } \\
\text { the old and new rules }\end{array}$ \\
\hline Costs of operation & Relatively low & Overcharged & Relatively high \\
\hline $\begin{array}{l}\text { The level of adoption of new } \\
\text { norms }\end{array}$ & $\begin{array}{l}\text { Low because new norms are } \\
\text { invisible / high because old rules } \\
\text { dominate }\end{array}$ & $\begin{array}{l}\text { Too high, when there is no need } \\
\text { for new norms / relatively low, } \\
\text { when needed }\end{array}$ & $\begin{array}{l}\text { A satisfactory option is the } \\
\text { average degree of alienation }\end{array}$ \\
\hline $\begin{array}{l}\text { The level of system stability to } \\
\text { transformation }\end{array}$ & Stable & Unstable & Urgently stable \\
\hline
\end{tabular}


- institutes that structure and make predictable the behavior of market partners (contract law) and more.

These mechanisms are almost impossible to borrow in finished form, so you have to create your own. Transitional societies have such a name because they are unstable and can remain in that state for a long time. However, the Ukrainian experience suggests that, under certain conditions, the transition model may have stable equilibrium traits.

There are several indicators when society and the economy cease to be transitional. From a quantitative point of view, market transformation is complete when GDP exceeds the pre-reform level.

Modern institutional theory is based on the premise that the transition ends when the formation of a new institutional foundation is completed. According to D. Nort's definition, "transition societies are societies in a state of institutional imbalance: finding a new equilibrium point in the institutional space means completing the"transition" (Nort, 2008).

\section{Conclusions}

There will be effective institutional forecasting if it provides, with other conditions being equal, minimal deviations from the results obtained. However, the requestor of institutional engineering is not always interested in establishing institutes that provide such savings. In general, the effectiveness of predictive analysis with forecasting and the effectiveness of institutes resulting from its implementation are different things, which are a consequence of the asymmetry of the distributional effects and the imbalances of the market environment generated by the rules, as well as their incompleteness.

The importance of analyzing institutional change, both positive and regulatory, in the modern world is extremely high: institutional change is taking place almost continuously in all economic systems, not only in the EU, but also in developing countries. Some have a positive effect on the further development of the economy, others, on the contrary, contribute to stagnation, while there are some who do not affect economic behavior at all.

Massive institutional changes are also occurring at the level of individual economic organizations: firms, corporations, etc. There are also examples of successful and unsuccessful changes. Therefore, their study should be the subject of continuous scientific and applied research.

If we look at the world economic history, we can state that no country, since the era of liberalism, has successfully completed the construction of the national state and national economy under the rules of liberalism. Only the conditions of strict protectionism, state monopoly and control contributed to the consolidation of society and economic growth. Necessary tools for the formation of national unity in the country are the priority development of education, culture, army, and police. Despite the fact that laws and state institutes are not directly engaged in production, but they directly affect the reproduction of productive forces. The nation must recoup a part of material wealth in order to support culture, skill and the unification of productive forces (Gukasyan, 2013).

Interest in the predictive analysis of institutionalism and the market environment is growing significantly in the face of a crisis that has recently become a dominant feature of the global economy. The level of economic development of the market environment is directly related to the quality of the institutional environment. Vulnerability to external financial and economic shocks increases with the duration of deformation of the institutional environment. In our view, in order to gain sustainable economic development, sustainable economic growth, it is necessary that the macroeconomic equilibrium be supplemented by the institutional equilibrium, the criterion of which is the fulfillment of functions entrusted to them by society and ensuring its development as a whole, uniform distribution of income, formation of middle class.

\section{References:}

Borovkov, A. A. (22 June 2013). Probability Theory. Springer Science \& Business Media.

Bilenko, Y. (2013). Deformations of the institutional environment and their impact on economic growth in central and eastern Europe. Visnyk of the Lviv University. Series International Relations. Issue 32, pp. 207-215.

Bolotina, E., \& Shubnaya, E. (2016). Institutional modifications a. traectory institutional development. Economic Bulletin of Donbass. № 3(45).

Brennan, Dzh., \& Biukenen, Dzh. (2005). Prychyna pravyl. Konstytutsyonnaia polytycheskaia ekonomyia [Reason rules. Constitutional Political Economy]. Sankt-Peterburg: Ekonomycheskaia shkola.

Djankov, S., Glaeser, E., \& La Porta R. (2013). The new comparative economics. Journal of Comparative Economics. No. 31(4), pp. 598-600.

David, P. (1985). Clio and Economics of QWERTY. American Economic Review. Vol. 75, No. 2, pp. $12-19$.

Gukasyan, G. M. (2013). Economic theory: problems of the "new economy" Genesis of science. Neoinstitutionalism. The theory of globalization. 2nd ed. Sankt-Peterburg.

Holubka, S. M. (2015). Institutional paradigm genesis and evolution of the financial sector of Ukraine. Doctor of economic science Thesis, Economic Theory and History of Economic Thought, State Educational and Scientific Institution, Kyiv. 
Hodgson, J. (2006). Evolutionary and institutional economics as a new "mainstream". Economic Bulletin of Rostov State University. No. 2, Volume 6.

Institute for Public Policy (2018). Barometer of Public Opinion, April. Retrieved from: http://www.ipp.md

Kaufmann D. Kraay \& M. Mastruzzi (2010). The Worldwide Governance Indicators: Methodology and Analytical IssuesGovernance. Draft Policy Research Working Paper, Washington, DC :World Bank. September, 2010. Retrieved from: http://econ.worldbank.org/external

Kleiner, G. B. (2004). The evolution of institutional systems. Moscow: Science.

Kovalenko, Y. (2013). Instytutsionalizatsiia finansovoho sektoru ekonomiky [The institutionalization of the financial sector]. National University of STS of Ukraine, Irpen.

Kouz, R. (1993). Fyrma, rynok y pravo [Firm, market and law]. Moskow: Delo LTD.

Lance, D., \& North, C. Douglass (1970). Institutional change and American Economic Growth: A First Step Toward a Theory of Institutional Innovation. Journal of Economic History. № 30.

Lin, J. Y. (1989). An Economic Theory of Institutional Change: Induced and Imposed change. Justin Yifu Lin. Cato Journal. Vol. 9. № 1.

Martynyuk, O. (2015). Formation of the imperatives of sustainable development for structural transformations of the economy. Bulletin of the Odessa National University. Series: Economics. Volume 20. Issue 6.

Sala-i-Martin, X. (2002). Fifteen years of new growth economics: what have we learned? Economic Growth: Sources, Trends, and Cycles, edited by Norman Loayza and Raimundo Soto. Santiago, Chile: Central Bank of Chile.

Sukharev, O. S. (2011). Institutional Change, Efficiency and Structure of Economy. Saarbrucken: Lambert Academic Publishing.

Sukharev, O. S. (2011). Elementary model of Institutional Change and Economic Welfare. Montenegrin Journal of Economics. Vol. 7, No. 2.

The Worldwide Governance indicators (2019). Retrieved from: http://info.worldbank.org/wgi/

Tambovtsev, V. L. (2005). Fundamentals of Institutional Design. Moscow: INFRA-M.

Nort, D. (2008). Instytutsii, instytutsijna zmina ta funktsionuvannia ekonomiky [Institutions and institutional changes in economy]. Kyiv: Osnovy.

Veblen, T. (1980). The theory of the empty class. Moscow: Progress.

Yaremenko, O. L. (2007). Institutions and economic freedom of economic entities. Economic theory. No. 3. 